\title{
Factors Standing Against Listening Success
}

\author{
Siham Bouzar Eps Fodil-Cherif \\ English department/ University of Algiers2, Algeria \\ E-mail: sissifch@gmail.com
}

Received: August 30, 2017 Accepted: October 8, 2017 Published: October 10, 2017

doi:10.5296/elr.v3i2.11781ＵRL: http://doi.org/10.5296/elr.v3i2.11781

\begin{abstract}
The largest part of the time spent in the communication process is devoted to listening. This skill is in fact very important for developing any language learning proficiency. However, it sometimes constitutes a source of trouble and frustration for learners of English as a foreign language (EFL) who find themselves unable to comprehend the spoken message transmitted to them in the target language. Therefore, this article explores the factors standing against the comprehension of the oral input in a way to open the path for thinking about measures to overcome listening difficulties.
\end{abstract}

Keywords: Listening skill, Comprehensible input, Listening comprehension difficulties

\section{Introduction}

For many years, listening skill was denied priority in language teaching. It was assumed that listening in a second language could be acquired through exposure to authentic language but not explicitly taught. Thus, instructional methods were mainly focused on productive skills. It was only until recently that this stand has changed to be substituted by an active interest in instructing listening comprehension skills as its role is at the heart of second language acquisition. Additionally, various investigations had been realised in this field in a perspective to provide teachers with a clear picture of how to diagnose learners' listening obstacles and how to transcend them.

\section{The Nature of Hearing and Listening}

From the literature review on listening instruction, it was only after 1970's that considerable changes in listening training took place, in which much broader understanding started to emerge including the very definition of listening itself. Indeed, until quite recently listening comprehension or "the Cinderella skill", as referred to by Nunan (2002: 238), won the interest of scholars and became a prerequisite for oral proficiency as well as an important skill in its own right. It is now "recognized as an important facet of language learning" (Morley, 2001: 69). Yet, before tackling the concept of listening, the distinction between 
hearing and listening needs to be set out.

\subsection{Hearing versus Listening}

By examining the definitions attributed both to hearing and listening, we find that these two concepts differ from each other. In fact, Devito's definition of hearing as "a passive physiological process where vibrations impose on your eardrums and requires little effort from you" (1992: 54 as cited in McMurray et al 2004: 223) exhibits the features of hearing. The latter is presented as being passive, requiring no reflection from the part of the hearer. Besides, it is involuntary as the sounds are received without the hearer's will. Moreover, it is effortless as it does not require the hearer to furnish any energy to receive the signals of the acoustic message transmitted. This definition is sustained by The Oxford English dictionary where Little et al (1973 as cited in Coles, 2002: 22) define hearing as "'the action of the faculty or sense by which sound is perceived". On the other hand, McMurray et al. (2004: 223) define listening as:

"an active process requiring effort on your part to connect with another by interpreting their signals and messages. Active listening requires the most energy because it requires serious attention and concentration".

Therefore, with reference to this definition, some features of listening can be stated. First, listening is an active process, which implies that it requires lot of energy from the part of the listener to concentrate and receive the signals attentively. Second, listening needs a lot of effort from the listener to receive the transmitted message, decipher it and comprehend it. Finally, listening involves the will of the listener to give an ear and pay attention to the aural discourse transmitted. In Rost's terms, it is "a process that is triggered by our attention" (1994: 2). A definition of listening as it is presented in this framework is also supported by The Oxford English dictionary where Little et al (1973 as cited in Coles, 2002: 22) define hearing as "the action or act of listening $[\ldots]$ to hear attentively $[\ldots]$ to give ear to [...] to pay attention to $[\ldots]$ to make an effort to hear something".

Obviously, from the definitions outlined above it appears that differentiating the concepts of listening and hearing constitutes an important step in discussing the features of the latter. Moreover, the ambiguity that was covering the issue existing between hearing and listening has been cleared up. Consequently, the rest of the discussion will be devoted to listening mainly as the present study focuses principally on the factors impeding learners to comprehend listening texts successfully.

\section{The Importance of Listening}

The crucial role that the listening skill plays in the educational process and in our daily life has been emphasised by many scholars (Krashen, 1982, 1985; Oxford, 1993; Rost, 1990; Rubin, 1995). As far as the instructional field is concerned, for instance, Oxford (1993: 205) stressed the importance of this receptive skill and argued that "listening is perhaps the most fundamental language skill". According to her, the development of learning cannot take place without listening.

Moreover, research suggests that there is no output from the part of the learners unless there exists a comprehensible input (Krashen, 1982, 1985). Therefore, learners attempting to acquire a second language are required to pay great attention to listening to the target 
language, which is not an easy task. According to Rubin (1995: 08), for second language/foreign language learners, listening constitutes "the skill that makes the heaviest processing demands because learners must store information in short term memory at the same time as they are working to understand the information". Likewise, Rubin explained, "Whereas in reading learners can go over the text at leisure, they generally do not have the opportunity to do so in listening".

The importance of this aural skill has also been emphasised by Rost (1991). According to the latter, listening as a skill is vital for the development of any foreign language learning. It constitutes the source from which the learner can retrieve vocabulary, the language system and the structures native speakers actually use. Therefore, teaching this skill in the language classroom should be targeted to achieve second language proficiency.

Continuing with the importance of listening, Burley -Allen (1995: 2) underlined the crucial role of this skill in our daily life on the ground of statistical calculations (see figure 01 forthcoming). According to him, the largest portion (40\%) of our daily communication is devoted to listening, with thirty five (35\%) being dedicated to speaking, sixteen $(16 \%)$ is devoted to reading and only nine (09\%) is occupied by writing.

From what had been addressed, it appears that scholars agree upon the fact that listening is a crucial skill for the development of language proficiency. This skill with its diverse types requires to be attributed the necessary consideration from the researchers acting in the field of listening comprehension. Thus, shedding light on the potential problems that may stand against the process of comprehension is felt necessary. These problems are addressed in the following section.

\section{Listening Comprehension Difficulties}

As it has been stated previously, though listening is categorised as a receptive skill, it does not match the passive character attributed to it. As a matter of fact, listening is much more complicated and highly demanding activity. Listening appears to be an on-going problem solving activity requiring lot of efforts from the learner to construct meaning. Accordingly, when dealing with listening difficulties, one can understand that they refer to the hurdles or potential problems impeding the listener from comprehending the message transmitted. In other words, listening difficulties refer to the factors influencing the failure of "input" (Krashen, 1985) reception. In this framework, before continuing in the elaboration of listening difficulties, it is important to pause and consider the concept related to "comprehensible input and stress its crucial role in promoting language development.

\subsection{The Comprehensible Input}

This concept is a term introduced by Krashen (1977, 1982, 1985 as cited in Allwright and Bailey 1991) to refer to "the language which the learners hear (or read) - that is, the language samples to which they are exposed" (Allwright \& Bailey, 1991). This definition implies that not all the transmitted data is understandable: only some of what they receive makes sense to them. Furthermore, with reference to Krashen, "language acquisition takes place through comprehension" (Nunan, 1999), that is foreign language learning cannot take place unless the input is comprehended. In Krashen's terms “comprehensible input is responsible for progress in language acquisition” (1982). 


\subsection{Investigations Tackling Listening Comprehension Difficulties}

Bearing in mind the tight link existing between learning and "comprehensible input" and in order to teach the listening skill efficiently by helping EFL learners to overcome their listening difficulties, various researchers (Underwood, 1989; Rubin, 1994, Goh, 2000, Hamouda, 2013; Walker, 2014) tackled this issue and mentioned some potential problems encountered by students. The latter are generally linked to the message to be listened to, the speaker, the listener, and the physical setting.

Indeed, Underwood (1989, as cited in Osada, 2004: 62) offered seven potential problems in learning to listen to English. They include speed of delivery, lack of repetition, limited vocabulary, signals recognition failure, lack of social and cultural knowledge, inability to concentrate and the attempt to decipher each word in the aural message. Firstly, speed of delivery is considered as an obstacle to efficient listening comprehension. According to Underwood, "many English language learners believe that the greatest difficulty with listening comprehension, as opposed to reading comprehension, is that the listener cannot control how quickly a speaker speaks" (Underwood, 1989). The second hurdle to listening is lack of repetition; ie, listeners cannot always have words repeated. The third area claimed to affect EFL listening comprehension is the student's limited vocabulary. In this respect, Underwood (1989) suggests the following:

"For people listening to a foreign language, an unknown word can be like a suddenly dropped barrier causing them to stop and think about the meaning of the word and thus making them miss the next part of the speec".

The fourth problem in listening is failure to recognize the signals indicating the move from one point to another, giving an example or repeating a point. In fact, signals such as "discourse markers, pauses, gestures, increased loudness, a clear change of pitch or different intonation patterns" (ibid in Osada, 2004: 62) are very helpful for proficient listeners in understanding the intended meaning; however, they can be misleading and constitute a source of ambiguity in case of lower level listenerscan.

Additionally, the lack of sociocultural and contextual knowledge of the target language represents the fifth obstacle to comprehension. Indeed, as language is culture specific, interpretation of the transmitted message is hard to reach for those who lack this knowledge. Thus, Underwood (1989:19) states, "students who are unfamiliar with the cultural context may have considerable difficulty in interpreting the words they hear even if they can understand their 'surface' meaning". The sixth source of trouble resides in the inability to concentrate. Thus, learners' interest should be taken into consideration during the selection or preparation of the listening materials. In this context, Underwood (1989) associates concentration with interest. According to him, "if students find the topic interesting, they will find concentration easier." The seventh and last difficulty facing EFL/ ESL listeners is the established learning habits to understand every word in the message.

Moreover, Rubin (1994: 199) listed five factors, in her review of 115 studies related directly to research in listening comprehension, that she believes affect the aural input comprehension. These factors are linked to "text characteristics, interlocutor characteristics, task characteristics, listener characteristics and process characteristics". 


\section{Macrothink}

Besides, in a research studying the difficulties faced by a group of 40 Chinese ESL learners and examining these difficulties within Anderson's (1995) three phase model of language comprehension, perception, parcing and utilisation, Goh (2000: 59) identified ten processing problems related to listening comprehension. She mentioned five problems experienced at the perception phase. The latter had mainly to do with "recognising sounds as distinct words or group of words". Perception difficulties also included problems of attention namely missing the next part of speech; missing the beginning of texts; incapacity to chunk streams of speech and lack of concentration. Regarding the utilisation phase, problems comprised "various difficulties with developing a coherent mental representation of words heard" (Goh, 2000: 59) such as quick forgetting of what is heard, inability to represent words in mind or understand subsequent parts of the input. In the utilisation stage, learners expressed problems with understanding the intended meaning of the input besides their inability to process the text further due to "either a lack of prior knowledge or inappropriate application of prior knowledge" (Goh, 2000)

Furthermore, Hamouda (2013) investigated the listening problems encountered by $60 \mathrm{EFL}$ first year Saudi students. He summarised the results of the research in eight major difficulties namely:

1) Rate of speech too fast to comprehend;

2) Limited English vocabulary;

3) Unclear pronunciation, different accents and dialects;

4) Difficulties related to listening strategies (forgetting to apply strategies, inability to apply strategies, ineffective use of strategy);

5) Poor knowledge of grammar;

6) The inability to concentrate (distractions inside and outside the class);

7) Lack of familiarity with the topic;

8) Problems pertaining to the length and difficulty of listening materials

Additionally, in an attempt to evaluate contemporary research with the aim of dissecting and discussing the reasons why the teaching of listening skills seems to be so complex and consequently suggesting some solutions for improving listening competence in the second language (L2) classroom, Walker (2014) stated some difficulties which students face namely pronounciation, stress and intonation. According to her the variety in pronounciation could be problematic in "the identification of words that constitute the oral discourse". In addition to that, prosodic characteristics of spoken discourse such as "where the stress falls, weak forms and strong forms of words and intonation" (Walker, 2014) also influence comprehension of the oral passage.

Furthermore, spoken discourse according to Walker (2014) is often presented in incomplete sentences in which "mispronounciation, hesitation, the rephrasing of utterances, repetition and even the loss of track of what is wanting to be said all play a role in verbal interaction". Another point to be considerd concerns vocabulary and grammar which may be confusing for learners as they "tend to be far more colloquial and much less formal" (ibid).

Another issue she considered is that listening requires instantaneous processing "with little or 
no option to access the spoken input again, making the skill arguably more complex than reading" she concluded by stating the sociolinguistic elements of listening "such as the student's cultural background and the student's knowledge of the cultural background of the foreign language" (Walker, 2014: 168) which can play a significant role in the understanding of the verbal discourse.

\section{Conclusion}

According to what has been reviewed in the literature regarding the potential problems in learning to listen to English, it is obvious that listening as a receptive skill is very complex. It requires lot of concentration, patience and will to overcome the difficulties. Some studies conducted in EFL context disclosed that these listening obstacles are rooted in four major factors: the listener, the spoken message, the speaker, and the physical setting. The insights literature puts forward would help in exploring the intricacies of this skill and explaining the potential problems facing learners and the possible solutions to improve listening processing.

\section{References}

Anderson, N. J. (1991). Individual Differences in Strategy use in Second Language Reading and Testing. Modern Language Journal, 75, 460-472. https://doi.org/10.1111/j.1540-4781.1991.tb05384.x

Burley-Allen, M. (1995). Listening the forgotten skill: A self-teaching guide (2nd Ed). New York, NY: John Wiley \& Sons, Inc.

Coles, A. (2002). Teaching strategies related to listening and hearing in two secondary classrooms. Research in Mathematics Education, 4(1), 21-34.

Goh, C. C. M (2000). A Cognitive Perspective on Language Learners' Listening $\begin{array}{llll}\text { Comprehension } \quad \text { Problems. } & \text { System, } & \text { 55-75. }\end{array}$ https://doi.org/10.1016/S0346-251X(99)00060-3

Krashen, S (1982). Principles and Practice in Second Language Acquisition (First Edition) Pergamon Press Inc.

Little, W., Fowler, H., \& Coulson, J. (1973). The Shorter Oxford English Dictionary, Clarendon Press, Oxford.

McMurray, A. J., Pace, R. W., \& Scott, D. (2004). Research: A Commonsense Approach. Tomson Social Science Press.

Nunan, D. (2002). Listening in Language Learning. In J, C. Richards, \& W, A. Renandya (Eds), Methodology in Language Teaching: an Anthology of Current Practice. Cambridge University Press. https://doi.org/10.1017/CBO9780511667190.032

Osada, N. (2004). Listening Comprehension Research: A Brief Review of the Last Thirty Years. TALK, Japan.

Oxford, R. L (1993). Research Update on Teaching L2 Listening. System, 21(2), 205-211. https://doi.org/10.1016/0346-251X(93)90042-F 


\section{Macrothink

Rost, M. (1994). Introducing Listening. London: Penguin English Applied Linguistics.

Underwood, M. (1989). Teaching Listening. New York: Longman.

\section{Copyright Disclaimer}

Copyright reserved by the author(s).

This article is an open-access article distributed under the terms and conditions of the Creative Commons Attribution license (http://creativecommons.org/licenses/by/3.0/). 